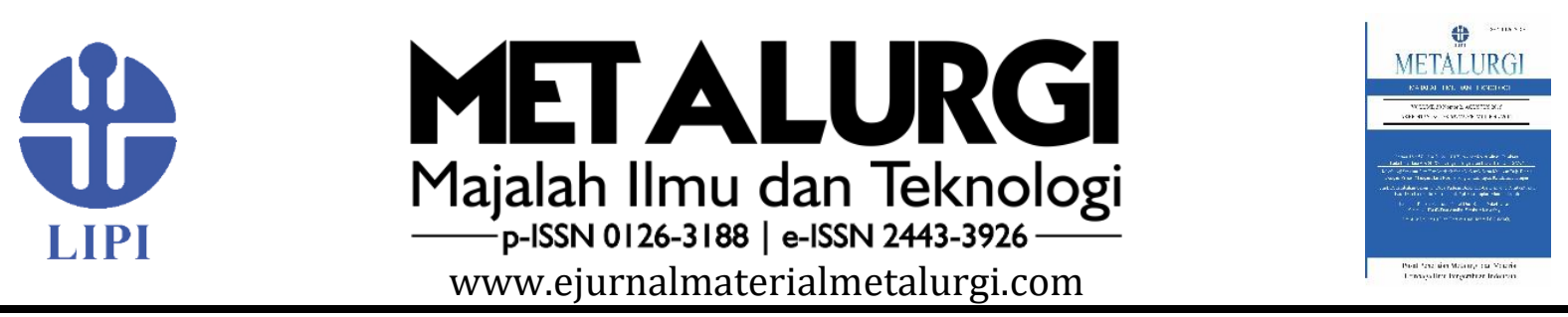

\title{
InCREASing OF Metal RECOVERY IN LEACHING PROCESS OF SPENT Catalyst at LoW Temperature: THE AdDition OF HYdROGEN PEROXIDE AND SODIUM CHLORIDE
}

\author{
Kevin Cleary Wanta ${ }^{a} *$, Edward Yonathan Natapraja ${ }^{a}$, Ratna Frida Susantia, \\ Gelar Panji Gemilar ${ }^{b}$, Widi Astutic ${ }^{i}$, Himawan Tri Bayu Murti Petrus ${ }^{d}$ \\ aDepartment of Chemical Engineering, Parahyangan Catholic University \\ Jalan Ciumbuleuit No. 94 Bandung, Indonesia 40141 \\ ${ }^{\text {bPT Petrokimia Gresik }}$ \\ Jalan Jenderal Ahmad Yani, Gresik, Indonesia 61119 \\ ${ }^{c}$ Research Unit for Mineral Technology, Indonesian Institute of Sciences (LIPI) \\ Jalan Ir. Sutami Km. 15, Tanjung Bintang, Lampung Selatan, Indonesia 35361 \\ ${ }^{\mathrm{d}}$ Department of Chemical Engineering, Gadjah Mada University \\ Jalan Grafika No. 2 Kampus UGM, Yogyakarta, Indonesia, 55281 \\ *E-mail: kcwanta@unpar.ac.id
}

Masuk tanggal : 07-07-2021, revisi tanggal : 31-08-2021, diterima untuk diterbitkan tanggal 09-09-2021

\begin{abstract}
Abstrak
Salah satu faktor yang memengaruhi proses leaching dari suatu sumber mineral adalah karakteristik mineral dari bahan baku tersebut. Tidak semua fasa mineral dapat terleaching secara langsung dan sempurna. Dengan demikian, beberapa mineral memerlukan perlakuan khusus sehingga proses leaching dapat berlangsung dengan maksimal. Studi ini akan terfokus pada mempelajari pengaruh penambahan senyawa aditif, yaitu hidrogen peroksida dan natrium klorida, dalam proses leaching spent catalyst dengan menggunakan larutan asam sulfat. Proses leaching dilakukan pada konsentrasi larutan asam sulfat $1 \mathrm{M}$ selama 240 menit pada suhu ruang. Konsentrasi hidrogen peroksida divariasikan pada $0-9 \% \mathrm{v} / \mathrm{v}$ sedangkan konsentrasi natrium klorida divariasikan pada $0-0,8 \mathrm{~mol} / \mathrm{L}$. Hasil percobaan menunjukkan bahwa kedua senyawa aditif tersebut mampu meningkatkan perolehan nikel secara signifikan. Perolehan nikel tertinggi sebesar 95,08\% tercapai saat penggunaan hidrogen peroksida sebesar $9 \% \mathrm{v} / \mathrm{v}$. Perolehan nikel ini lebih tinggi 3,5 kali dibandingkan dengan tanpa penambahan hidrogen peroksida. Sementara itu, konsentrasi natrium klorida sebesar $0,8 \mathrm{~mol} / \mathrm{L}$ mampu memberikan perolehan nikel tertinggi sebesar 50,38\% atau meningkat sebesar 1,9 kali bila dibandingkan dengan tanpa penambahan natrium klorida.
\end{abstract}

Kata Kunci: Leaching, spent catalyst, hidrogen peroksida, natrium klorida, nikel

\begin{abstract}
One of the factors that affect the leaching process of a mineral source is the mineral characteristics of the raw materials. Not all mineral phases can be leached completely and directly. Thus, some minerals require special treatment so that the leaching process can take place optimally. The purpose of this research is to investigate the effect of adding additive compounds, such as hydrogen peroxide and sodium chloride, to the leaching process of spent catalyst using a sulfuric acid solution. The leaching process was carried out at room temperature for 240 minutes with a concentration of $1 \mathrm{M}$ sulfuric acid solution. The highest nickel recovery of 95.08\% was obtained when hydrogen peroxide was used at a concentration of $9 \% \mathrm{v} / \mathrm{v}$. The experimental results showed that the two additive compounds were able to increase nickel recovery significantly. The highest nickel recovery of $95.08 \%$ was achieved when hydrogen peroxide was used at 9\%v/v. The nickel recovery is 3.5 times higher than without the addition of hydrogen peroxide. Meanwhile, a sodium chloride concentration of $0.8 \mathrm{~mol} / \mathrm{L}$ was able to provide the highest nickel recovery of $50.38 \%$, or a 1.9 times increase over the control.
\end{abstract}

Keywords: Leaching, spent catalyst, hydrogen peroxide, sodium chloride, nickel

DOI : http://dx.doi.org/10.14203/metalurgi.v36i2.591

(C) 2021 Metalurgi. This is an open access article under the CC BY-NC-SA license (https://creativecommons.org/licenses/by-nc-sa/4.0/)

Metalurgi is Sinta 2 Journal (https://sinta.ristekbrin.go.id/journals/detail?id=3708) accredited by Ministry of Research \& Technology, Republic Indonesia 


\section{INTRODUCTION}

The hydrometallurgical process, particularly the atmospheric pressure acid leaching (APAL) process, is a common method for metal recovery. The APAL process extracts and dissolves valuable metal ions into solvents from various mineral sources under atmospheric conditions. [1]-[2]. Some advantages of this process include the ability to obtain the product in purer conditions than the pyrometallurgical method, being more economical, requiring less energy, and being environmentally friendly [2]-[4].

In general, the main principle of the APAL process is to react solvent with metal compounds to produce metal ions that are easily soluble in aqueous solutions. During the leaching process, the diffusion step and the chemical reaction step control the rate of the leaching process. To improve the performance of the metal ion leaching process, various fundamental factors such as temperature, particle size, agitation, solvent type, solvent concentration, pulp density, and time are influenced [5]-[7].

However, mineral characteristics, the phase and form of minerals contained in the mineral resources, greatly affect the performance of the leaching process. Not all metal elements or compounds in the raw materials can be dissolved in the solvent directly and completely. In other words, it is needed an extra effort to leach the metal from the raw materials. For example, nickel will be easier to leach if the nickel contained in mineral sources is in $\mathrm{Ni}$ (II) ions or nickel-based compounds that can be changed into $\mathrm{Ni}$ (II) ions. Nickel metal $\left(\mathrm{Ni}^{\circ}\right)$ has properties that are slightly soluble in acids, such as sulfuric acid or hydrochloric acid, and insoluble in water [8][9]. Meanwhile, $\mathrm{Ni}(\mathrm{II})\left(\mathrm{Ni}^{2+}\right)$ ions are watersoluble, especially in the form of a nickel-based compounds such as nickel sulfate, nickel chloride, nickel nitrate, or nickel acetate [8]-[9].

The solubility of nickel or nickel-based compounds needs more attention when the leaching process is carried out on raw materials with a large enough nickel-metal $\left(\mathrm{Ni}^{\circ}\right)$ component, like a spent catalyst. Spent catalysts usually still have metal components in the form of pure metal elements. In the spent catalyst $\mathrm{Ni} / \gamma$ $\mathrm{Al}_{2} \mathrm{O}_{3}$, the nickel metal $\left(\mathrm{Ni}^{\circ}\right)$ is still much in the catalyst [10]. Because pure metal cannot be completely dissolved in an aqueous or acid solution, not all nickel can be leached. Thus, in addition to optimizing the fundamental factors, other efforts are required to maximize the nickel leaching process from this spent catalyst.

This study will focus on efforts to maximize nickel recovery in the leaching process using spent catalysts. The basic idea of this study is to convert the "insoluble" component of nickelmetal $\left(\mathrm{Ni}^{\circ}\right)$ into $\mathrm{Ni}(\mathrm{II})$ ions. As a result, these $\mathrm{Ni}$ (II) ions can react with other anions (from the solvent), such as $\mathrm{SO}_{4}{ }^{2-}$ ions, and form watersoluble salts. This idea is reinforced by observing the Pourbaix diagram of nickel, as shown in Fig. 1.

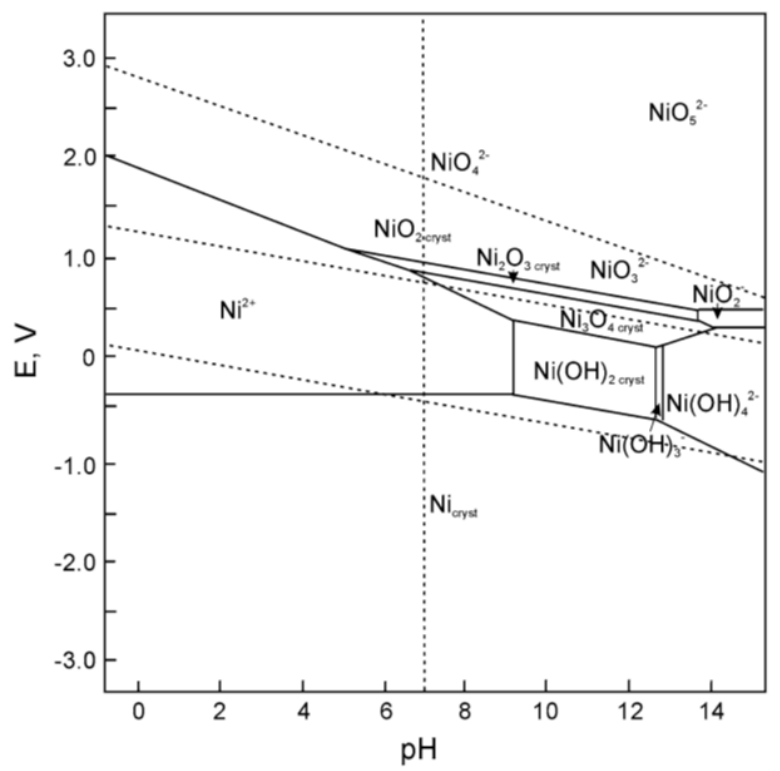

Figure 1. Pourbaix diagram of nickel in water [11]

In that Pourbaix diagram, $\mathrm{Ni}^{\circ}\left(\mathrm{Ni}_{\text {cryst }}\right.$, nickelmetal) is stable at all $\mathrm{pH}$ values as long as the voltage potential $(\mathrm{E})$ is below $-0.5 \mathrm{~V}$. If the voltage potential (E) is increased, $\mathrm{Ni}^{\circ}$ can be converted into $\mathrm{Ni}$ (II) $\left(\mathrm{Ni}^{2+}\right)$ ions. It is possible to make an effort by adding additive compounds such as hydrogen peroxide $\left(\mathrm{H}_{2} \mathrm{O}_{2}\right)$ or sodium chloride $(\mathrm{NaCl})$.

In the metal leaching process, hydrogen peroxide is a compound that can act as an oxidizing or reducing agent [12]. However, in an acidic medium, hydrogen peroxide acts more as an oxidizing agent [12]-[13]. Thus, hydrogen peroxide can oxidize lower valence metal elements/ions to higher valence metal (ions/ compounds). In the case of nickel metal $\left(\mathrm{Ni}^{\circ}\right)$ conversion from spent catalyst in sulfuric acid $\left(\mathrm{H}_{2} \mathrm{SO}_{4}\right)$ solution, hydrogen peroxide will oxidize $\mathrm{Ni}^{\circ}$ to $\mathrm{Ni}$ (II) ions or in the form of nickel oxide (NiO) compounds. This condition is desirable in this study because this oxidation process will produce nickel ions which can be dissolved in aqueous solution directly or indirectly through $\mathrm{NiO}$ compounds. Then, the $\mathrm{Ni}$ (II) ions will react with another anion $\left(\mathrm{SO}_{4}{ }^{2-}\right)$ or the $\mathrm{NiO}$ compounds will react with $\mathrm{H}_{2} \mathrm{SO}_{4}$ to form $\mathrm{NiSO}_{4}$ salt which is easily soluble in water. The reaction mechanism follows the following reaction equation [14]-[15]: 


\section{Oxidation reactions}

$\mathrm{Ni}_{(\mathrm{s})}=\mathrm{Ni}^{2+}($ aq $)+2 \mathrm{e}^{-}$

$\mathrm{E}=0,25 \mathrm{~V}$

$\mathrm{Ni}_{(\mathrm{s})}+\mathrm{H}_{2} \mathrm{O}_{2(\mathrm{aq})}=\mathrm{NiO}_{(\mathrm{s})}+\mathrm{H}_{2} \mathrm{O}_{(\mathrm{l})}$

Dissolution reactions

$\mathrm{Ni}^{2+}{ }_{(\mathrm{aq})}+\mathrm{H}_{2} \mathrm{SO}_{4(\mathrm{aq})}=\mathrm{NiSO}_{4(\mathrm{aq})}+2 \mathrm{H}^{+}{ }_{(\mathrm{aq})}$

$\mathrm{NiO}_{(\mathrm{s})}+\mathrm{H}_{2} \mathrm{SO}_{4(\mathrm{aq})}=\mathrm{NiSO}_{4(\mathrm{aq})}+\mathrm{H}_{2} \mathrm{O}_{(\mathrm{l})}$

Overall reaction

$$
\begin{aligned}
\mathrm{Ni}_{(\mathrm{s})}+\mathrm{H}_{2} \mathrm{O}_{2(\mathrm{aq})}+\mathrm{H}_{2} \mathrm{SO}_{4(\mathrm{aq})} & \\
& =\mathrm{NiSO}_{4(\mathrm{aq})}+2 \mathrm{H}_{2} \mathrm{O}_{(\mathrm{l})}
\end{aligned}
$$

In the absence of hydrogen peroxide, $\mathrm{Ni}^{\circ}$ will not be leached into an aqueous solution. Therefore, the use of hydrogen peroxide has excellent potential to increase nickel recovery in the leaching process in an acidic medium [16]-[18].

Another additive that is applied to improve the performance of the leaching process is chloride salts, such as sodium chloride $(\mathrm{NaCl})$. The addition of chloride salts to the sulfate leaching medium is mostly done for the chalcopyrite leaching process [19]. Some chloride-based compounds such as ferric chloride $\left(\mathrm{FeCl}_{3}\right)$, cupric chloride $\left(\mathrm{CuCl}_{2}\right)$, sodium chloride $(\mathrm{NaCl})$ are good oxidizing agents [20]. The addition of chloride salts, such as $\mathrm{NaCl}$ into the leaching system can increase the complex formed in the solution [4], [20]-[22]. Besides, the $\mathrm{NaCl}$ (chloride salts) addition is also expected to increase the voltage potential. Thus, chloride salts may be able to convert elements/compounds in the passive area (pure metal) into ions that are easily soluble in an aqueous solution. This concept will be applied in the nickel leaching process from the spent catalyst. Based on the Pourbaix diagram of nickel in Figure 1, the nickel-metal $\left(\mathrm{Ni}^{\circ}\right)$ phase is in the passive zone which is insoluble in an aqueous solution. The addition of salt in the system is expected to convert $\mathrm{Ni}^{\circ}$ into $\mathrm{Ni}$ (II) ions. Sodium chloride compounds also increase the formation of complex compounds so that the nickel recovery process will be better [4], [20]-[22]. In addition, the addition of salt, such as $\mathrm{NaCl}$, into sulfuric acid can increase the electrolyte level of the solution [23]. It is possible that during the extraction process, the value of the voltage potential (E) will also increase so that the possibility that $\mathrm{Ni}^{\circ}$ turns into $\mathrm{Ni}$ (II) ions becomes larger (based on Fig. 1).

This study is designed on a spent catalyst leaching process using the sulfuric acid solution at room temperature. The effect of adding additives, such as $\mathrm{H}_{2} \mathrm{O}_{2}$ and $\mathrm{NaCl}$, on nickel and aluminum recovery is investigated. The leaching process at room temperature requires a very long processing time if the desired metal recovery is high. These low operating conditions have the advantage of lower energy use. As a result, the findings of this study are expected to have a positive impact, allowing metals to be obtained with high recovery and in a short period of time.

\section{Materials ANd MethodS \\ 2.1 Materials}

Spent catalysts used in this study were the catalysts that had been saturated from the reforming process at PT Petrokimia Gresik. A solution of sulfuric acid $\left(\mathrm{H}_{2} \mathrm{SO}_{4}\right)$ was used as a solvent at a concentration of $1 \mathrm{M}$. Other materials such as hydrogen peroxide $\left(\mathrm{H}_{2} \mathrm{O}_{2}\right)$ and sodium chloride $(\mathrm{NaCl})$ were also used as additives.

\subsection{Procedure}

The leaching process took place using a series of equipment, as shown in Fig. 2.

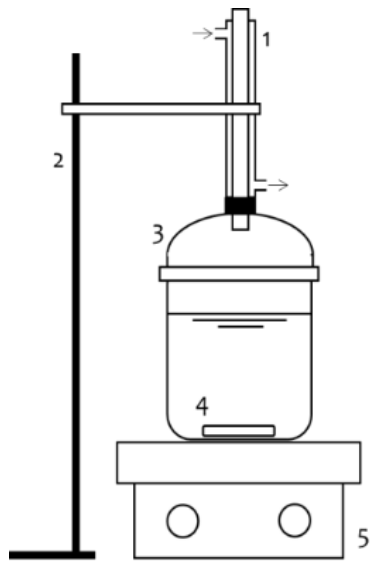

1. Condensor

2. Stand, boss, and clamp

3. Leaching vessel

4. Magnetic stirrer

5. Hotplate

Figure 2. Leaching equipment

After the equipment was assembled, $300 \mathrm{ml}$ of 1 $\mathrm{M} \mathrm{H}_{2} \mathrm{SO}_{4}$ solution was poured into the leaching vessel. A solution of $\mathrm{NaCl}$ or $\mathrm{H}_{2} \mathrm{O}_{2}$ at a certain concentration was mixed with that $\mathrm{H}_{2} \mathrm{SO}_{4}$ solution. The concentration of $\mathrm{H}_{2} \mathrm{O}_{2}$ solution was varied in the range of $0-9 \% \mathrm{v} / \mathrm{v}$ while the concentration of $\mathrm{NaCl}$ was varied in the range of 0-0.8 mol/L. Then, the temperature of this mixture was adjusted at $30{ }^{\circ} \mathrm{C}$ and stirred at 200 rpm. After the desired operating conditions are achieved, 60 grams of spent catalyst, with a size of -200 mesh, was entered into the leaching vessel. This step indicated that the leaching had been started and counted as $t=0$. A sampling of $10 \mathrm{ml}$ was carried out periodically at 30,90, and 240 minutes. This sample was first separated between the solid phase and the liquid phase. The liquid phase formed was then analyzed for the content of $\mathrm{Ni}$ (II) ions using AAS (atomic absorption spectrometry) and Al(III) ions using a $\mathrm{UV}-\mathrm{V}$ is spectrophotometer. 


\subsection{Data Analysis}

The percentage recovery of metal ions was calculated using the following equation.

$\%$ Recovery $=\frac{\mathrm{C}_{\mathrm{t}}}{\mathrm{C}_{\mathrm{o}}} \times 100 \%$

where $\mathrm{C}_{\mathrm{t}}$ is the concentration of dissolved metal $\left(\mathrm{Ni}^{2+}\right.$ or $\left.\mathrm{Al}^{3+}\right)$ ions at $\mathrm{t} ; \mathrm{C}_{\mathrm{o}}$ is the maximum concentration of metal $\left(\mathrm{Ni}^{2+}\right.$ or $\left.\mathrm{Al}^{3+}\right)$ ions in spent catalysts.

\section{ReSUlts AND Discussions}

\subsection{The Characteristics of Spent Catalyst}

As the raw material, the spent catalysts used in this study were characterized first. The material characterization carried out consisted of the constituent composition and the mineral phase contained in the catalyst. The composition of the catalyst is known by analyzing the sample using XRF ( $\mathrm{x}$-ray fluorescence). The analysis result is presented in Table 1 .

Table 1 . The composition of raw materials

\begin{tabular}{cc}
\hline Element & Composition (wt.\%) \\
\hline $\mathrm{Al}$ & 38.22 \\
$\mathrm{Ni}$ & 37.66 \\
$\mathrm{Ca}$ & 22.61 \\
$\mathrm{P}$ & 0.44 \\
$\mathrm{Fe}$ & 0.43 \\
$\mathrm{~K}$ & 0.23 \\
$\mathrm{Si}$ & 0.22 \\
\hline
\end{tabular}

Table 1 shows that the constituent elements of this spent catalyst are dominated by aluminum $(\mathrm{Al})$ and nickel $(\mathrm{Ni})$. These analysis results are in line with the analysis results for the mineral phase contained in the catalysts. The mineral phase was analyzed using XRD (x-ray diffraction) and the analysis results are presented in Fig. 3.

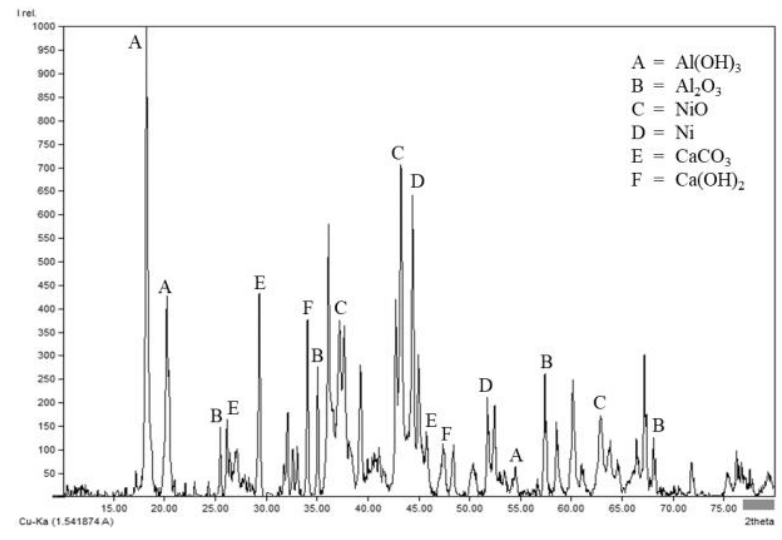

Figure 3. XRD pattern for raw materials

The analysis result using XRD in Fig. 3 shows that the catalyst used comprises a mineral phase $\mathrm{Al}(\mathrm{OH})_{3}, \mathrm{Al}_{2} \mathrm{O}_{3}, \mathrm{NiO}, \mathrm{Ni}, \mathrm{CaCO}_{3}$, dan $\mathrm{Ca}(\mathrm{OH})_{2}$.
For the nickel leaching process, two nickel phases can be utilized, i.e. $\mathrm{NiO}$ and $\mathrm{Ni}^{\circ}$ (nickelmetal) phases. It is easy to obtain nickel from the $\mathrm{NiO}$ phase because the reaction between $\mathrm{NiO}$ and the solvent $\left(\mathrm{H}_{2} \mathrm{SO}_{4}\right)$ can be carried out directly by following the reaction equation (4). However, for the leaching process from the $\mathrm{Ni}^{\circ}$ phase, nickel can not be leached directly. In Fig. 3, nickelmetal $\left(\mathrm{Ni}^{\circ}\right)$ has a reasonably high intensity, especially at $44.3^{\circ}$ and $51.8^{\circ}$. Nickel under this phase will be the focus of this study. $\mathrm{Ni}^{\circ}$ is expected to be reduced from the spent catalyst by leaching with the addition of $\mathrm{H}_{2} \mathrm{O}_{2}$ or $\mathrm{NaCl}$. The addition of both additives can oxidize $\mathrm{Ni}^{\circ}$ to become $\mathrm{Ni}$ (II) ions and then, those ions dissolve in an aqueous solution.

\subsection{The Effect of Hydrogen Peroxide $\left(\mathrm{H}_{2} \mathrm{O}_{2}\right)$ Addition on the Leaching Process of Spent Catalyst}

In this section, the parameter studied is the concentration of hydrogen peroxide compounds. The variations used for this parameter are $0 ; 1.5$; and $9 \% \mathrm{v} / \mathrm{v}$. The experimental results are presented in Fig. 4.

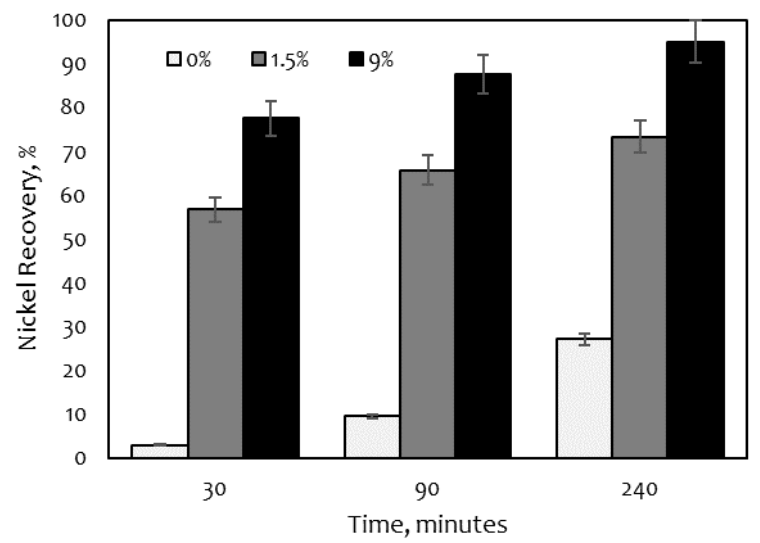

Figure 4 . The effect of hydrogen peroxide addition on nickel recovery

A certain concentration of hydrogen peroxide added to the system has a significant effect on the nickel recovery process. The experimental results in Fig. 4 demonstrate this. This is evidenced by the experimental results in Fig. 4. According to the experimental results, the higher the hydrogen peroxide concentration, the higher the nickel recovered.

Based on Fig. 4, the highest nickel percentage was achieved at $95.08 \%$ using hydrogen peroxide at $9 \% \mathrm{v} / \mathrm{v}$ and a leaching time of 240 minutes. The results obtained are reasonable and in line with the existing theory. Long operating duration increases the probability of a molecule interacting with the others. This condition will optimize the leaching process 
mechanism and can recover more nickel. However, when the leaching time was 30 minutes, the use of hydrogen peroxide increased significantly when compared to the difference in nickel recovery. When compared to the percentage of nickel recovery without the addition of hydrogen peroxide, the addition of hydrogen peroxide at 30 minutes can increase nickel recovery by 19.5 times for a concentration of $1.5 \% \mathrm{v} / \mathrm{v}$ and 26.6 times for a concentration of $9 \% \mathrm{v} / \mathrm{v}$.

The results of this experiment indicate that using hydrogen peroxide in the nickel leaching process is an intriguing and promising endeavor. This process was carried out at room temperature, where this operating condition is classified as low temperature. In general, leaching at low temperatures results in a low percentage of recovery, or it takes a very long time if a high percentage of recovery is desired. The experiments conducted in this study, on the other hand, demonstrated that hydrogen peroxide was capable of providing high recovery in a relatively short time and at low temperatures.

As explained in the introduction section, hydrogen peroxide acts as an oxidizing agent and will oxidize $\mathrm{Ni}^{\circ}$ (insoluble) to $\mathrm{Ni}$ (II) ions (soluble). This phenomenon causes the percentage of nickel recovery will increase after the addition of hydrogen peroxide. Fig. 5 shows that the intensity of the $\mathrm{Ni}$ phase decreases significantly when the residue sample is treated with hydrogen peroxide. This is visible at $44.3^{\circ}$. The results of this XRD analysis support the findings of previous studies, demonstrating that the leaching process with the addition of $\mathrm{H}_{2} \mathrm{O}_{2}$ has been successfully optimized because $\mathrm{Ni}^{\circ}$ has been converted into $\mathrm{Ni}(\mathrm{II})$ ions and dissolves in acid. As a result, the nickel recovery percentage increased very significantly.

Unlike the nickel leaching process, the addition of hydrogen peroxide in this study does not provide a significant difference to the aluminum recovery process. This can be seen in Fig. 6. The leaching process at all concentrations of hydrogen peroxide only gave an average percentage of aluminum recovery of $42.5 \pm 4 \%$. When it views from the mineral phase present in the spent catalyst (Fig. 3), aluminum is not in a pure metal phase but the $\mathrm{Al}_{2} \mathrm{O}_{3}$ and $\mathrm{Al}(\mathrm{OH})_{3}$ phases which can directly react with sulfuric acid, then form $\mathrm{Al}(\mathrm{III})$ ions. These $\mathrm{Al}(\mathrm{III})$ ions will dissolve in an acidic medium and form $\mathrm{Al}_{2}\left(\mathrm{SO}_{4}\right)_{3}$ salt. The reaction equations that occur are [24][25]:

$$
\begin{aligned}
& \mathrm{Al}_{2} \mathrm{O}_{3(\mathrm{~s})}+3 \mathrm{H}_{2} \mathrm{SO}_{4(\mathrm{aq})}=\mathrm{Al}_{2}\left(\mathrm{SO}_{4}\right)_{3(\mathrm{aq})}+3 \mathrm{H}_{2} \mathrm{O}_{(\mathrm{l})} \\
& \mathrm{Al}(\mathrm{OH})_{3(\mathrm{~s})}+3 \mathrm{H}_{2} \mathrm{SO}_{4(\mathrm{aq})}=\mathrm{Al}_{2}\left(\mathrm{SO}_{4}\right)_{3(\mathrm{aq})}+3 \mathrm{H}_{2} \mathrm{O}_{(\mathrm{l})}
\end{aligned}
$$

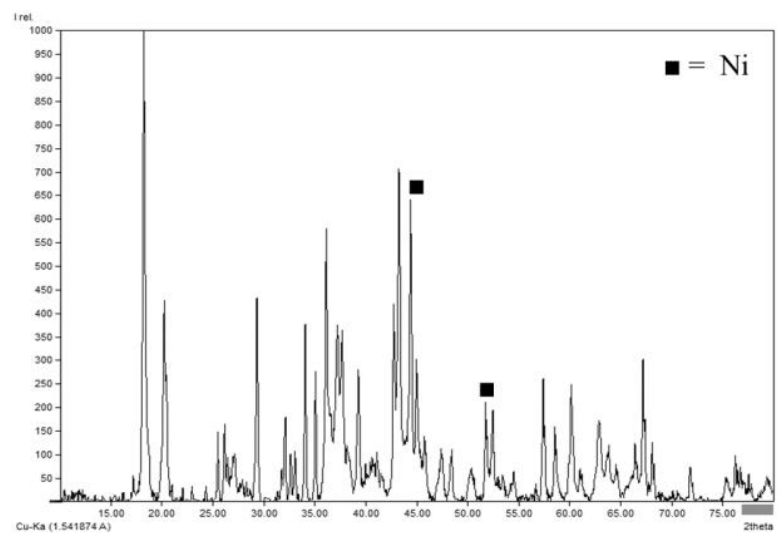

(a)

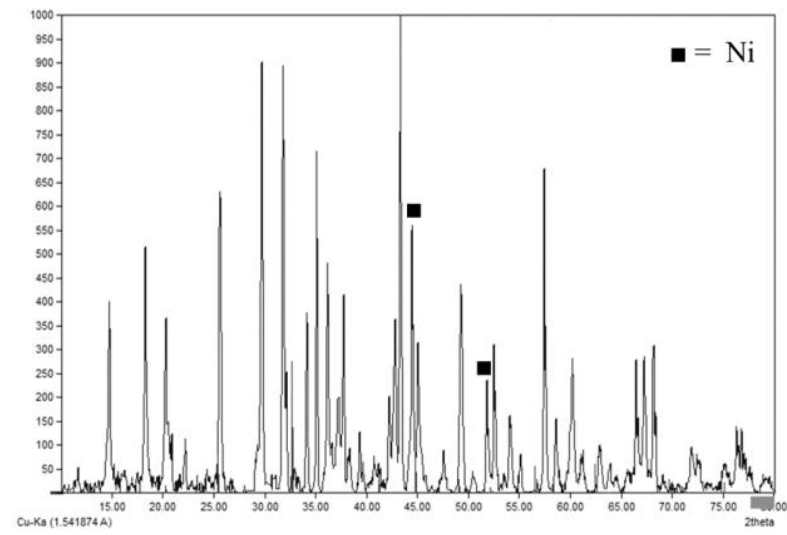

(b)

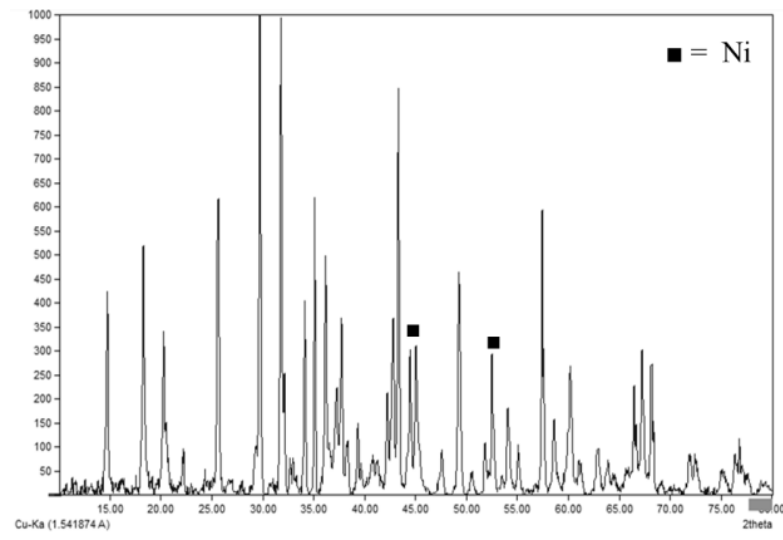

(c)

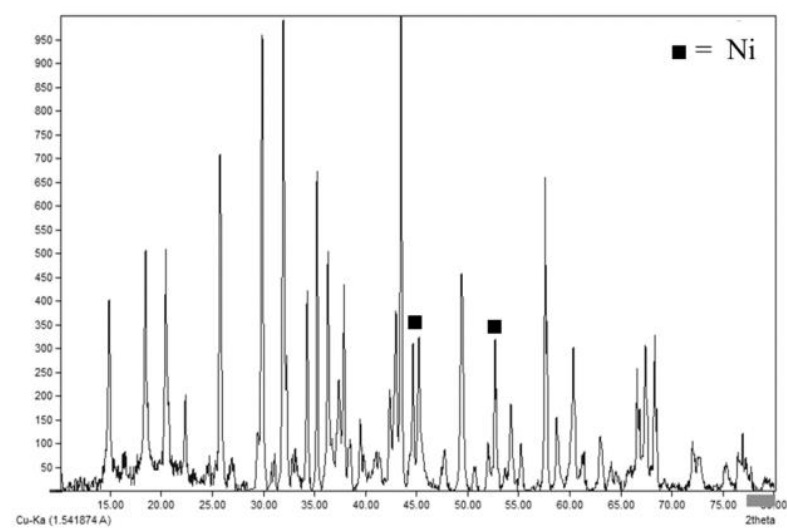

(d)

Figure 5. XRD pattern (a) raw materials and residue from leaching process (b) without the addition of $\mathrm{H}_{2} \mathrm{O}_{2}$, (c) with the addition $\mathrm{H}_{2} \mathrm{O}_{2}$ by $1.5 \% \mathrm{v} / \mathrm{v}$, and (d) $9 \% \mathrm{v} / \mathrm{v}$ 


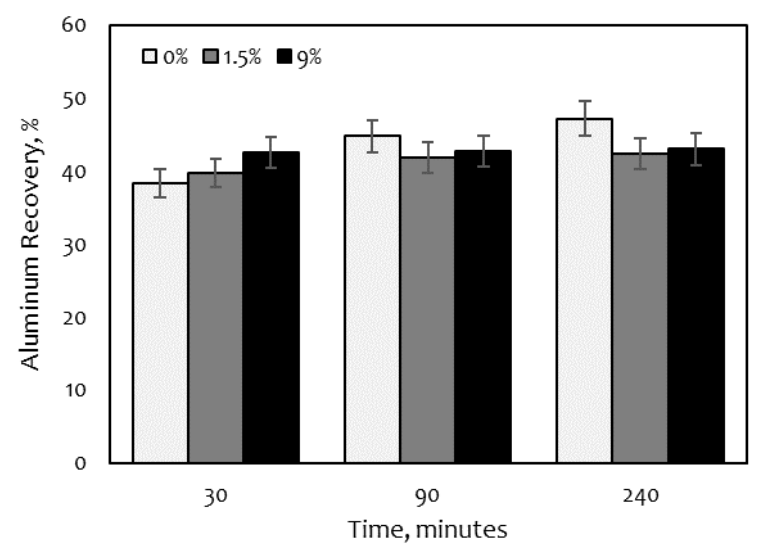

Figure 6. The effect of hydrogen peroxide addition on aluminum recovery

In other words, for the leaching process of this spent catalyst, the use of hydrogen peroxide has more effect on the nickel recovery.

\subsection{The Effect of Sodium Chloride ( $\mathrm{NaCl}$ ) Addition on the Leaching Process of Spent Catalyst}

Another parameter studied in this study is the addition of salt, i.e. sodium chloride $(\mathrm{NaCl})$ during the leaching process. The salt concentration was varied at $0,0.1$, and $0.8 \mathrm{~mol} / \mathrm{L}$. For this study, there is no addition of hydrogen peroxide into the system. The effect of this variation can be observed from the percentage of nickel recovery, as shown in Fig. 7.

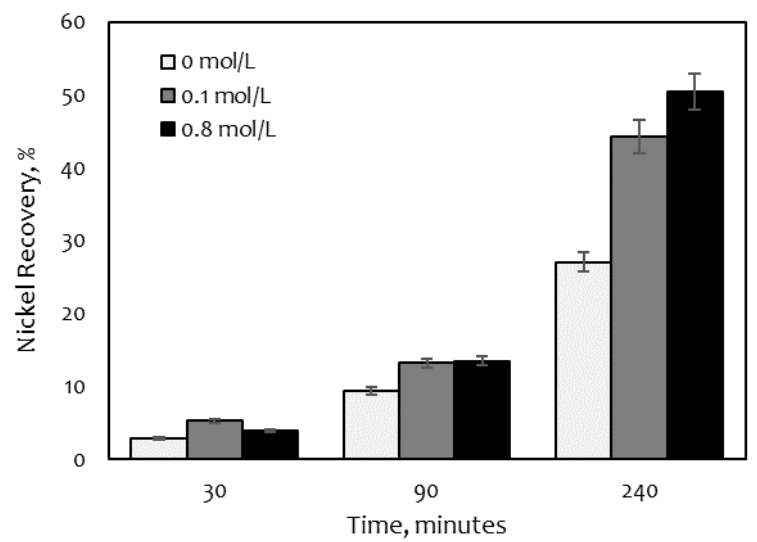

Figure 7. The effect of sodium chloride addition on nickel recovery

Figure 7 shows that the addition of sodium chloride during the leaching process has a positive impact on nickel recovery as the leaching process takes longer. This condition is very obvious, especially at the 240 minutes leaching time. For 240 minutes, sodium chloride was able to increase the percentage of nickel recovery from $27.07 \%$ to $44.25 \%$ (for the addition of $0.1 \mathrm{~mol} / \mathrm{L} \mathrm{NaCl}$ ) and $50.38 \%$ (for the addition of $0.8 \mathrm{~mol} / \mathrm{L} \mathrm{NaCl}$ ). The phenomenon resulting from this study is a promising effort to maximize the nickel leaching process. The effect of sodium chloride as an additive is not as significant as hydrogen peroxide. However, the addition of sodium chloride was able to increase nickel recovery by about two times even though the leaching process was carried out at a low temperature, $30{ }^{\circ} \mathrm{C}$ where the leaching rate at this temperature was prolonged.

The use of sodium chloride can convert the nickel phase from $\mathrm{Ni}^{\circ}$ to $\mathrm{Ni}(\mathrm{II})$ ions because theoretically, there is an increase in the voltage potential value. This result is further proven from the results of analyzing the mineral phase of the residue from the leaching process. The results of the analysis are presented in Fig. 8. Based on Fig. 8 , the nickel-metal $\left(\mathrm{Ni}^{\circ}\right)$ phase decreased significantly after the addition of sodium chloride. This can be observed from the XRD pattern and peak intensity of the $\mathrm{Ni}^{\circ}$ phase, especially at $44.3^{\circ}$ and $51.8^{\circ}$. The decrease in peak intensity and increase in nickel recovery further strengthens the study results where the addition of sodium chloride can increase the rate of nickel leaching process from spent catalyst.

Furthermore, when Fig. 7 is compared to Fig. 4 , there is a difference in the tendency of the addition of hydrogen peroxide and sodium chloride. A comparison of the two figures shows that the addition of sodium chloride is not as aggressive as hydrogen peroxide. Increasing the time of 30 and 90 minutes in sodium chloride did not result in a significant increase in nickel recovery. This is in contrast to the addition of hydrogen peroxide, where the difference in time significantly increases nickel recovery. This phenomenon indicates that the oxidation process of $\mathrm{Ni}^{\circ}$ to $\mathrm{Ni}$ (II) ions will be more spontaneous when hydrogen peroxide is added.

An analysis of aluminum recovery was also performed for this parameter, and the results are shown in Fig. 9. In general, no significant changes occurred in aluminum recovery. This condition is similar to the study of the addition of hydrogen peroxide. However, Fig. 9 has a consistent trend in each leaching time. The addition of $0.1 \mathrm{~mol} / \mathrm{L}$ sodium chloride gives slightly better leaching results. In this condition, the recovered aluminum is in the range of 45.66$48.68 \%$. This study shows that, like hydrogen peroxide, the addition of sodium chloride has an effect on the nickel leaching process when compared to aluminum. 


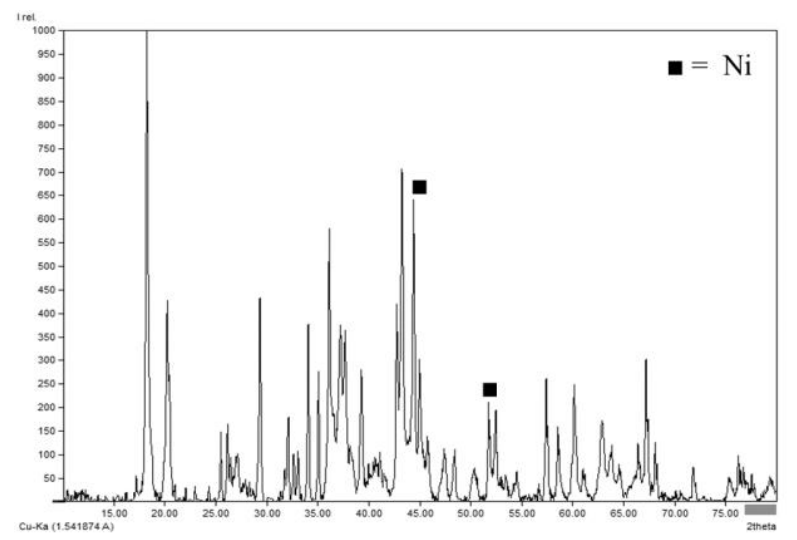

(a)

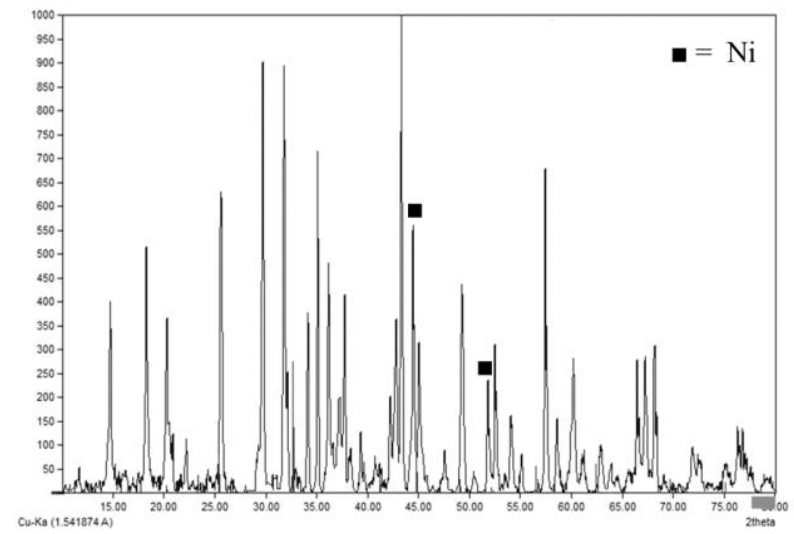

(b)

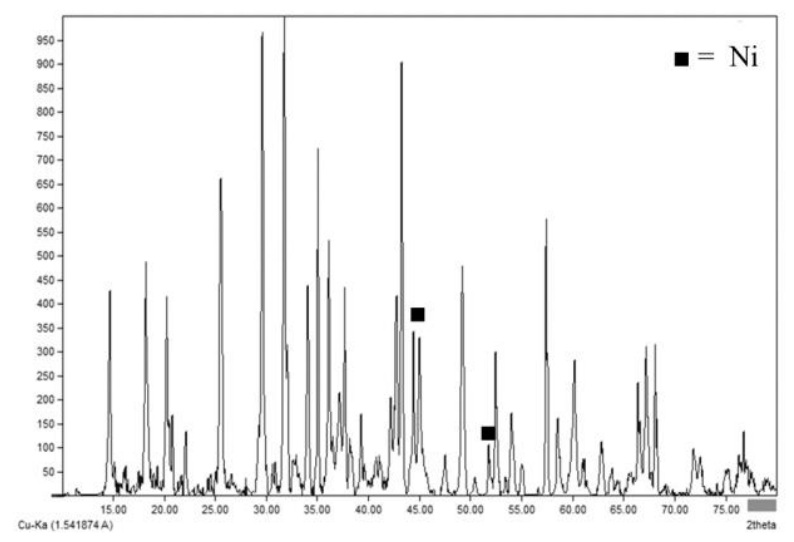

(c)

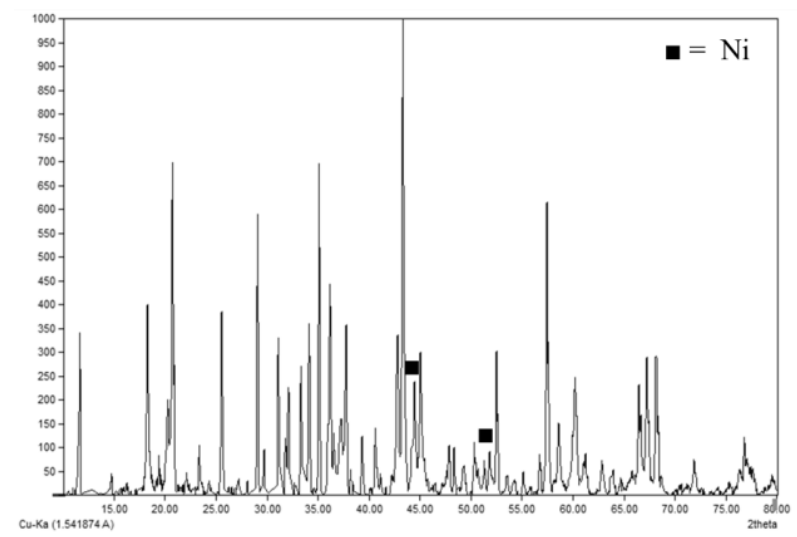

(d)

Figure 8. XRD pattern (a) raw materials and residue from leaching process (b) without the addition of $\mathrm{NaCl}$, (c) with the addition $\mathrm{NaCl}$ by $0.1 \mathrm{~mol} / \mathrm{L}$, and (d) $0.8 \mathrm{~mol} / \mathrm{L}$

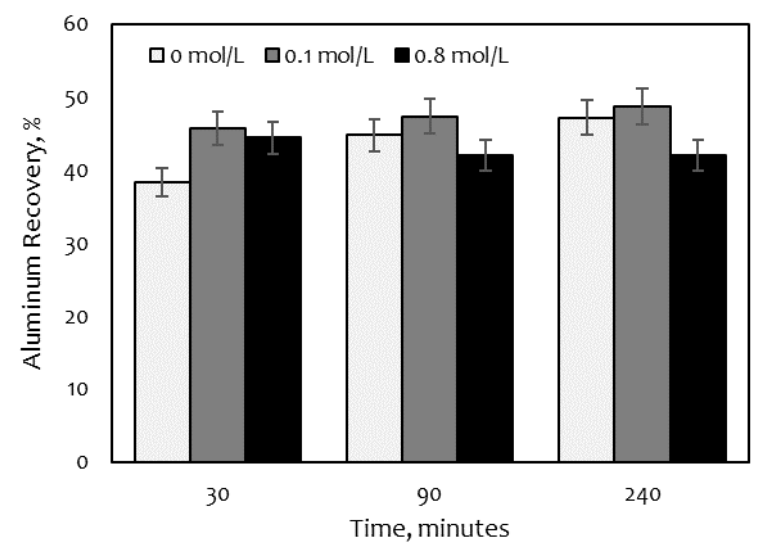

Figure 9. The effect of sodium chloride addition on aluminum recovery

Overall, the results of this experiment are supported by the results obtained from several previous studies [16]-[18], [20]-[22]. Those studies confirmed that hydrogen peroxide and sodium chloride are the good additive agent for the metal recovery, especially nickel in the low temperature extraction process. Both additives have a positive effect to leaching process becaust the nickel metal $\left(\mathrm{Ni}^{\circ}\right)$ phase contained in the spent catalysts can be extrated into the acid solution.

\section{Conclusions}

The addition of additives such as hydrogen peroxide and sodium chloride has a positive effect on the nickel leaching process from the spent catalyst. These two additive compounds are capable of converting nickel metal $\left(\mathrm{Ni}^{\circ}\right)$ into $\mathrm{Ni}(\mathrm{II})$ ions which are easily soluble in an aqueous solution. As a result, the use of these additive compounds can increase nickel recovery. In general, the higher the concentration of additive compounds, the higher the nickel recovery. In this study, the use of hydrogen peroxide concentration of $9 \% \mathrm{v} / \mathrm{v}$ was able to leach nickel by $95.08 \%$ or an increase of 3.5 times when compared to without the addition of hydrogen peroxide. Meanwhile, the use of sodium chloride of $0.8 \mathrm{~mol} / \mathrm{L}$ was able to leach nickel by $50.38 \%$ or an increase of 1.9 times. However, the use of these two additive compounds did not tend to affect the aluminum recovery.

\section{ACKNOWLEDGEMENT}

The author would like to express gratitude to PT. Petrokimia Gresik and LIPI's Science Services for Research Laboratorium for their assistance.

\section{REFERENCES}

[1] K. C. Wanta, W. Astuti, I. Perdana, and H. T. B. M. Petrus, "Kinetic study in 
atmospheric pressure organic acid leaching: Shrinking core model versus lump model," Minerals, vol. 10, no. 7, pp. 1-10, 2020. Doi: 10.3390/min10070613

[2] K. Korkmaz, "Comparative study of high pressure and atmospheric acid leaching for the extraction of nickel and cobalt from refractory nickel laterite ores," Middle East Technical University, Ankara, Turkey, Thesis, May, 2014.

[3] K. C. Wanta, F. H. Tanujaya, R. F. Susanti, H. T. B. M. Petrus, I. Perdana, and W. Astuti, "Studi kinetika proses atmospheric pressure acid leaching bijih laterit limonit menggunakan larutan asam nitrat konsentrasi rendah," J. Rekayasa Proses, vol. 12, no. 2, p. 19, 2018. Doi: 10.22146/jrekpros.35644

[4] R. G. McDonald and B. I. Whittington, "Atmospheric acid leaching of nickel laterites review. Part I. Sulphuric acid technologies," Hydrometallurgy, vol. 91, no. 1-4, pp. 35-55, 2008. Doi: 10.1016/j.hydromet.2007.11.009

[5] W. Astuti, T. Hirajima, K. Sasaki, and N. Okibe, "Comparison of effectiveness of citric acid and other acids in leaching of low-grade Indonesian saprolitic ores," Miner. Eng., vol. 85, pp. 1-16, 2016. Doi: 10.1016/j.mineng.2015.10.001

[6] X. Fan, W. Xing, H. Dong, J. Zhao, Y. $\mathrm{Wu}, \mathrm{B}$. Li, W. Tong, X. Wu "Factors research on the influence of leaching rate of nickel and cobalt from waste superalloys with sulfuric acid," Int. J. Nonferrous Metall., vol. 02, no. 02, pp. 63-67, 2013. Doi: 0.4236/ijnm.2013. 22008

[7] H. B. T. M. Petrus, K. C. Wanta, H. Setiawan, I. Perdana, and W. Astuti, "Effect of pulp density and particle size on indirect bioleaching of Pomalaa nickel laterite using metabolic citric acid," IOP Conf. Ser. Mater. Sci. Eng., vol. 285, no. 1, 2018. Doi: 10.1088/1757-899X/285/1/ 012004

[8] IARC Working Group, "Nickel and nickel compounds", in IARC Monographs on the Evaluation of Carcinogenic Risks to Humans, vol. 49, Lyon, France: International Agency for Research on Cancer, WHO, pp. 263-266, 1990.

[9] E. Nielsen, P. B. Larsen, Nickel, inorganic and soluble salts. Evaluation of health hazards and proposal of a health based quality criterion for drinking water. Copenhagen, Denmark: The Danish
Environmental Protection Agency, 2013.

[10] K. C. Wanta, F. D. Putra, R. F. Susanti, G. P. Gemilar, W. Astuti, S. Virdhian, and H. T. B. M. Petrus, "Pengaruh derajat keasaman $(\mathrm{pH})$ dalam proses presipitasi hidroksida selektif ion logam dari larutan ekstrak spent catalyst," J. Rekayasa Proses, vol. 13, no. 2, p. 94, 2019. Doi: 10.22146/jrekpros.44007

[11] F. Ciesielczyk, P. Bartczak, K. Wieszczycka, K. Siwińska-Stefańska, M. Nowacka, and T. Jesionowski, "Adsorption of $\mathrm{Ni}$ (II) from model solutions using co-precipitated inorganic oxides," Adsorption, vol. 19, no. 2-4, pp. 423-434, 2013. Doi: 10.1007/s10450-0129464-5

[12] A. O. Adebayo, K. O. Ipinmoroti, and O. O. Ajayi, "Dissolution of chalcopyrite with hydrogen peroxide in sulphuric acid," Pak. J. Sci. Ind. Res., vol. 49, no. 2, pp. 65-71, 2006.

[13] A. Szymczycha-Madeja, "Kinetics of Mo, $\mathrm{Ni}, \mathrm{V}$ and $\mathrm{Al}$ leaching from a spent hydrodesulphurization catalyst in a solution containing oxalic acid and hydrogen peroxide," J. Hazard. Mater., vol. 186, no. 2-3, pp. 2157-2161, 2011. Doi: 10.1016/j.jhazmat.2010.11.120

[14] H. Li, S. Li, J. Peng, C. Srinivasakannan, L. Zhang, and S. Yin, "Ultrasound augmented leaching of nickel sulfate in sulfuric acid and hydrogen peroxide media," Ultrason. Sonochem., vol. 40, pp. 1021-1030, 2018.2 Doi: 10.1016/j.ultsonch.2017.08.031

[15] M. A. Rabah, F. E. Farghaly, and M. A. Abd-El Motaleb, "Recovery of nickel, cobalt and some salts from spent Ni-MH batteries," Waste Manag., vol. 28, no. 7, pp. 1159-1167, 2008. Doi: 10.1016/j.wasman.2007.06.007

[16] M. A. Rabah, "Recovery of aluminium, nickel-copper alloys and salts from spent fluorescent lamps," Waste Manag., vol. 24, no. 2, pp. 119-126, 2004. Doi: 10.1016/j.wasman.2003.07.001

[17] N. S. Randhawa, K. Gharami, and M. Kumar, "Leaching kinetics of spent nickel-cadmium battery in sulphuric acid," Hydrometallurgy, vol. 165, pp. 191-198, 2016. Doi: 10.1016/j.hydromet.2015.09. 011

[18] E. Rudnik and M. Nikiel, "Hydrometallurgical recovery of cadmium and nickel from spent $\mathrm{Ni}-\mathrm{Cd}$ batteries," Hydrometallurgy, vol. 89, no. 
1-2, pp. 61-71, 2007. Doi: 10.1016/j.hydromet.2007.05.006

[19] M. F. C. Carneiro and V. A. Leão, "The role of sodium chloride on surface properties of chalcopyrite leached with ferric sulphate," Hydrometallurgy, vol. 87, no. 3-4, pp. 73-82, 2007. Doi: 10.1016/j.hydromet.2007.01.005

[20] K. H. Park, D. Mohapatra, K. Hong-In, and G. Xueyi, "Dissolution behavior of a complex $\mathrm{Cu}-\mathrm{Ni}-\mathrm{Co}-\mathrm{Fe}$ matte in $\mathrm{CuCl}_{2}$ $\mathrm{NaCl}-\mathrm{HCl}$ leaching medium," Sep. Purif. Technol., vol. 56, no. 3, pp. 303-310, 2007. Doi: 10.1016/j.seppur.2007.02.013

[21] M. Skrobian, T. Havlik, and M. Ukasik, "Effect of $\mathrm{NaCl}$ concentration and particle size on chalcopyrite leaching in cupric chloride solution," Hydrometallurgy, vol. 77, no. 1-2, pp. 109-114, 2005. Doi: 10.1016/j.hydromet.2004.10.015

[22] R. Winand, "Chloride hydrometallurgy," Hydrometallurgy, vol. 27, pp. 285-316, 1991. Doi: 10.1016/0304-386X(91) 90055-Q

[23] M. Mungkin, "Studi pengaruh bahan aditif $\mathrm{NaCl}$ dan $\mathrm{Na}$-EDTA pada elektrolit baterai berbahan filtrasi air jeruk nipis," vol. 3, no. 1, pp. 2-7, 2018.

[24] L. S. Li, Y. S. Wu, Y. Y. Liu, and Y. C. Zhai, "Extraction of alumina from coal fly ash with sulfuric acid leaching method," Guocheng Gongcheng Xuebao/The Chinese J. Process Eng., vol. 11, no. 2, pp. 254-258, 2011.

[25] A. Zhao, T. A. Zhang, G. Lv, and W. Tian, "Kinetics of the leaching process of an australian gibbsitic bauxite by hydrochloric acid," Adv. Mater. Sci. Eng., vol. 2016, pp. 1-7, 2016. Doi: $10.1155 / 2016 / 5813542$ 
86 | Metalurgi, V. 36.2.2021, P-ISSN 0126-3188, E-ISSN 2443-3926/ 77-86 